\title{
Evaluating Strip Tillage and Rowcover Use in Organic and Conventional Muskmelon Production
}

\author{
Jennifer Tillman ${ }^{1}$, Ajay Nair ${ }^{1,3}$, Mark Gleason $^{2}$, and Jean Batzer ${ }^{2}$
}

ADDITIONAL INDEX WORDs. black plastic mulch, cereal rye, cover crop, cucurbit, roller crimper, spunbonded

SUMMARY. Increasing interest in using cover crops and reduced tillage to build soil health has created a demand for strategies to implement rolled cover crop systems. In northern areas of the United States, cool soil temperature in rolled cover crop systems can create a challenge when growing warm season vegetable crops. The use of rowcovers could mitigate the issue and facilitate adoption of rolled cover crop systems for both conventional and organic growers. This study investigated muskmelon (Cucumis melo) in two production systems, strip tillage (ST) into rolled cereal rye (Secale cereale) or conventional tillage with black plastic mulch (plasticulture), with or without the use of spunbonded polypropylene rowcovers. The trial was conducted in two fields, one in organic management and the other in conventional management. In general, ST led to cooler, moister soils than plasticulture, but rowcovers rarely affected soil temperature. Rowcovers increased mean and maximum daily air temperature by up to 4.2 and $11.7^{\circ} \mathrm{C}$, respectively, and decreased average daily light intensity by $33 \%$ to $37 \%$. Rowcovers sometimes increased fruit size, but rarely affected marketable yield. Overall, ST reduced marketable yield compared with plasticulture by 6732 to $9900 \mathrm{lb} /$ acre; however, ST with rowcovers often produced similar vegetative growth compared with plasticulture without rowcovers. Given the slow vining growth habit of muskmelon and the late planting inherent in a rolled cereal rye system, achieving high muskmelon yields, especially early yields, may be difficult.

$\mathrm{C}$ urrent cucurbit production systems in the United States often rely on tillage and plastic film mulches to create favorable growing conditions of warm soils and minimal weed pressure around plants; however, there are environmental concerns about the disposal of plastic mulches (Hemphill, 1993). An alternative would be to use biodegradable film mulches, but they are often prohibitively expensive (Kasirajan and Ngouajio, 2012). In addition, to achieve adequate soil to plastic

This work was supported by USDA Specialty Crop Research Initiative grant no. 2012-51181-20295.

We thank Vince Lawson and Justin Rinas at the Muscatine Island Research and Demonstration Farm for their invaluable help managing the field experiments and Cynthia Cambardella and Jody Ohmacht at the National Laboratory for Agriculture and the Environment for their help analyzing soil microbial biomass carbon. We also thank the graduate and undergraduate students from Iowa State University who helped with field and laboratory work. Seeds for the project were donated by Syngenta Seeds.

This paper is part of a thesis by Jennifer Tillman for an M.S. degree.

${ }^{1}$ Department of Horticulture, 106 Horticulture Hall, Iowa State University, Ames, IA 50011

${ }^{2}$ Department of Plant Pathology and Microbiology, 351 Bessey Hall, Iowa State University, Ames, IA 50011

${ }^{3}$ Corresponding author. E-mail: nairajay@iastate.edu. contact with film mulches, intensive tillage is used, but this practice can degrade soil health as it can harm soil microbes (Jackson et al., 2003), decrease soil carbon (Roper et al., 2010), and decrease earthworm diversity (Pelosi et al., 2014). These factors, and others, are indicators of soil health, as they can be used to measure the soil's ability to sustain and support a viable ecosystem. Interest in preserving soil health and building topsoil is increasing among organic and conventional growers, and a focus on cover crop usage and reduced tillage systems could minimize negative impacts on soil chemical, biological, and physical properties (Balota et al., 2014; Doran, 1987; Roper et al., 2010; Wyland et al., 1996).

Reduced tillage systems can produce similar or greater yields compared with conventional tillage systems in several vegetable crops such as carrot [Daucus carota (Brainard and Noyes, 2012)], cabbage [Brassica oleracea (Haramoto and Brainard, 2012)], pepper [Capsicum annuum (Delate, 2008)], pumpkin [Cucurbita pepo (Rapp et al., 2004)], summer squash [C. pepo (Nesmith et al., 1994)], sweet corn [Zea mays (Luna and Staben, 2002)], and zucchini [C. pepo (Canali et al., 2013)].

Although reduced tillage systems can increase long-term soil productivity and health, several drawbacks may discourage the adoption of these practices. Growers may confront issues with soil compaction (Salem et al., 2015) and weeds in the years transitioning to reduced tillage (Peigné et al., 2007) and soil temperature can be reduced when some reduced tillage strategies are employed (Canali et al., 2013; Licht and Al-Kaisi, 2005). Depending on the crop, location, and time of year, growers may face reduced yields compared with conventional tillage (Bottenberg et al., 1997; Hoyt et al., 1994).

One method of reduced tillage involves seeding a cover crop in the fall, most commonly cereal rye, and allowing it to reach anthesis in the spring. A roller crimper is then used to kill the cover crop, thus creating organic mulch for the cash crop. Cash crops could be planted either using a no-tillage approach or by creating a narrow tilled strip into which cash

\begin{tabular}{lllc}
\hline $\begin{array}{l}\text { Units } \\
\text { To convert U.S. to SI, } \\
\text { multiply by }\end{array}$ & U.S. unit & SI unit & $\begin{array}{l}\text { To convert SI to U.S., } \\
\text { multiply by }\end{array}$ \\
\hline 10.7639 & $\mathrm{fc}$ & $\operatorname{lumen}(\mathrm{s}) / \mathrm{m}^{2}$ & 0.0929 \\
0.3048 & $\mathrm{ft}$ & $\mathrm{m}$ & 3.2808 \\
0.0283 & $\mathrm{ft}^{3}$ & $\mathrm{~m}^{3}$ & 35.3147 \\
3.7854 & gal & $\mathrm{L}$ & 0.2642 \\
2.54 & inch $(\mathrm{es})$ & $\mathrm{cm}$ & 0.3937 \\
25.4 & inch $(\mathrm{es})$ & $\mathrm{mm}$ & 0.0394 \\
0.4536 & $\mathrm{lb}$ & $\mathrm{kg}$ & 2.2046 \\
1.1209 & $\mathrm{lb} / \mathrm{acre}$ & $\mathrm{kg} \cdot \mathrm{ha}^{-1}$ & 0.8922 \\
0.0254 & $\mathrm{mil}$ & $\mathrm{mm}$ & 39.3701 \\
28.3495 & $\mathrm{oz}$ & $\mathrm{g}$ & 0.0353 \\
33.9057 & $\mathrm{Oz} / \mathrm{yard}^{2}$ & $\mathrm{~g} \cdot \mathrm{m}^{-2}$ & 0.0295 \\
$\left({ }^{\circ} \mathrm{F}-32\right) \div 1.8$ & ${ }^{\circ} \mathrm{F}$ & ${ }^{\circ} \mathrm{C}$ & $\left({ }^{\circ} \mathrm{C} \times 1.8\right)+32$ \\
& & &
\end{tabular}


crops are seeded or transplanted. Benefits of ST into rolled cover crops include reduction in weeds between rows (Leavitt et al., 2011; Smith et al., 2011), soil erosion protection (Creamer and Dabney, 2002), and preservation of soil structure. In addition, ST provides warmer soil in the planting zone compared with no till (Licht and Al-Kaisi, 2005). However, rolled cover crop mulches can tie up nitrogen $(\mathrm{N})$ in grass-based cover crop systems (Delate, 2008) and decrease soil temperature compared with conventional tillage (Leavitt et al., 2011). Crop planting may also be delayed since cereal rye must reach anthesis to be effectively ended by a roller crimper (Mirsky et al., 2009). Nevertheless, rolled cover crops are becoming an increasingly popular strategy in reduced tillage operations.

Rowcovers can increase temperature of both the air and soil (Gogo et al., 2014; Ibarra et al., 2001; Nair and Ngouajio, 2010), and have been shown to increase yields in various vegetable crops such as muskmelon (Cline et al., 2008; Saalau Rojas et al., 2011), french bean [Phaseolus vulgaris (Gogo et al., 2014)], and watermelon [Citrullus lanatus (Soltani et al., 1995)]. Rowcovers serve as a physical barrier for the plants, reducing insect damage, disease spread (Saalau Rojas et al., 2011), and movement of pests that lay eggs near plants (Cline et al., 2008). This can be particularly important in regions where cucurbit bacterial wilt (Erwinia tracheiphila), spread by spotted and striped cucumber beetles (Diabrotica undecimpunctata and Acalymma vittatum, respectively) is a major factor in yield loss.

The goal of this experiment was to determine if a rolled cereal rye ST system could be as productive for muskmelon in Iowa as a standard system of plasticulture through the added use of rowcovers.

\section{Materials and methods Study site}

The study was conducted at the Muscatine Island Research and Demonstration Farm in Fruitland, IA (lat. $041^{\circ} 21^{\prime} 15^{\prime \prime} \mathrm{N}$, long. $091^{\circ} 08^{\prime} 08^{\prime \prime}$ W). Fields used in 2013 and 2014 were adjacent. The 2013 field had been previously in a poor stand of sorghum sudangrass (Sorghum bicolor), and the 2014 field had been previously in a corn/soybean (Z. mays/ Glycine max) rotation under conventional management. Soils are categorized as well-drained, fruitfield coarse sand (sandy, mixed, mesic Entic Hapludolls).

\section{Experimental design}

In each year, a split-plot design with four replications was used in adjacent organically and conventionally managed fields. In both years, the organically managed field was not certified organic. Production system was the main plot factor (ST into rolled cereal rye or conventional tillage with black plastic mulch) and rowcover was the subplot factor (rowcover or no rowcover). Experimental units in each replication consisted of 18 plants per $31-\mathrm{ft}$ row. One row of muskmelon separated whole plot treatments and acted as a guard row, as no data were collected from it.

\section{Field implementation}

Organically and conventionally managed fields were separated by a 12-ft-wide buffer area. Organic management consisted of using organically certified seeds, fertilizer, and insecticides. Conventional management consisted of using treated seeds and synthetic fertilizer, insecticides, and herbicides.

Field operation timing is summarized in Table 1 . Cereal rye was drilled in Oct. 2012 at $50 \mathrm{lb} /$ acre. Because of a marginal cereal rye stand in 2013, the rate was increased to 110 $\mathrm{lb} / \mathrm{acre}$ the following season.

To prepare ST plots, cereal rye was rolled with a roller crimper (I \& J Manufacturing, Gap, PA) within 1 week of reaching anthesis to maximize kill and minimize regrowth (Mirsky et al., 2009). This was followed by a single pass of the strip tiller $(6000$ Strip-Till; Hiniker Co., Mankato, $\mathrm{MN})$. When establishing the strips in 2013 , it was challenging to get the strip tiller to run smoothly because of heavy cereal rye residue, so in 2014 , an extra pass with the strip tiller was made in April before cereal rye stem elongation. Distance between melon rows was $6 \mathrm{ft}$ center to center. Drip tape (12 inches emitter spacing, $0.45 \mathrm{gal} /$ min per $100 \mathrm{ft}$ ) was laid on the surface in the strip tilled region.

To prepare the plasticulture plots, cereal rye was mowed and tilled in May. The plots were again tilled in
June before using a plastic mulch layer to create 6 - $\mathrm{ft}$ center-to-center raised beds and lay drip tape under black plastic mulch $(0.9$ mil thick, $4 \mathrm{ft}$ wide). A timer was used to irrigate all fields with $0.07 \mathrm{inch} / \mathrm{d}$ of water initially, gradually increasing to 0.27 inch/d by the end of the season.

Granular fertilizer was applied and incorporated after tillage operations, but before establishing raised beds. Rate of fertilizer application was based on a preplant soil test for $\mathrm{N}$, phosphorus $(\mathrm{P})$, and potassium $(\mathrm{K})$. In 2013, ST plots received half of the total fertilizer preplant and the other half at rowcover removal, whereas plasticulture plots received all fertilizer preplant. Total fertility applied was $95 \mathrm{lb} /$ acre of $\mathrm{N}$ using urea $(46 \mathrm{~N}-$ $0 \mathrm{P}-0 \mathrm{~K})$ for conventional plots and an organic fertilizer with the composition of $5 \mathrm{~N}-0.4 \mathrm{P}-0.8 \mathrm{~K}$ (Fertrell Co., Bainbridge, PA) for organic plots.

In 2014, a system was designed for the conventionally managed field to fertigate $\mathrm{N}$ through drip irrigation. We were unable to find an organic fertilizer compatible with our fertigation system. The conventionally managed field received one-third of the total $\mathrm{N}$ fertilizer preplant and the rest through fertigation. All $\mathrm{K}$ fertility was applied preplant. The organically managed field received all fertilizer preplant. Total fertility applied was $150 \mathrm{lb} /$ acre of $\mathrm{N}$ and $83 \mathrm{lb} /$ acre of $\mathrm{K}$ using urea and potassium chloride [KCl $(0 \mathrm{~N}-0 \mathrm{P}-49.8 \mathrm{~K})]$ preplant and urea ammonium nitrate $(32 \mathrm{~N}-0 \mathrm{P}-$ $0 \mathrm{~K})$ through fertigation for the conventional field and $4 \mathrm{~N}-0.9 \mathrm{P}-3.3 \mathrm{~K}$ (Fertrell Co.) for the organic field.

Untreated 'Athena' muskmelon seeds (Syngenta Seeds, Gilroy, CA) and organic potting mix (Mix \#ll; Beautiful Land Products, West Branch, IA) were used for the organic field, and insecticide-treated seeds were used for the conventional field. Seeds were planted into 98-cell trays in mid-May of both years. Transplants were planted using a mechanical transplanter (Mulch Planter 1265; Holland Transplanter Co., Holland, MI) in early June of both years with an in-row spacing of 22 inches.

Wire hoops were placed every $4 \mathrm{ft}$ down the row and spunbonded rowcovers (Agribon AG-30; Polymer Group, Charlotte, NC) were installed the same day of transplanting. Rowcover edges were buried in plasticulture 
Table 1. Timeline of treatment establishment in muskmelon trials in Fruitland, $\mathrm{IA}$, in 2013 and 2014.

\begin{tabular}{lcc}
\hline Operation & $\mathbf{2 0 1 3}$ & $\mathbf{2 0 1 4}$ \\
\hline Drilled cereal rye cover crop, variety unknown & 12 Oct. 2012 & 2 Oct. 2013 \\
Established strip tillage plots & - & 8 Apr. \\
Took soil samples for nutrient recommendation & 1 May & 23 Apr. \\
Muskmelon seeded into 98-cell trays & 9 May & 12 May \\
Mowed and incorporated cereal rye (plasticulture) & 9 May & 29 May \\
Roller-crimped cereal rye at anthesis (strip tillage) & 22 May & 29 May \\
Re)established strips (strip tillage) & 3 June & 29 May \\
Tilled and laid plastic (plasticulture) & 3 June & 5 June \\
Transplanted muskmelon, installed rowcovers & 4 June & 10 June \\
Opened rowcover ends & 11 July & 10 July \\
Removed rowcovers & 18 July & 17 July \\
\hline
\end{tabular}

plots and were weighed down with water-filled lay-flat hose in ST plots to avoid disturbing the rolled cereal rye. These methods also prevented tearing the rowcover fabric so it could be used again. Rowcover ends were opened and pinned up when $50 \%$ of plants had female flowers. Rowcovers were removed $7 \mathrm{~d}$ later.

Plots with no rowcovers received an insecticide treatment at planting. An imidacloprid drench (Admire; Bayer CropScience, Research Triangle Park, NC) was used in the conventionally managed field and spinosad (Entrust SC; Dow AgroSciences, Indianapolis, IN) combined with a feeding stimulant (Cidetrak D; Trécé, Adair, OK) was applied as a band spray in the organically managed field. After rowcovers were removed, plants in the organically managed field were sprayed weekly with kaolin clay (Surround WP; Tessenderlo Kerley, Phoenix, AZ), an insect deterrent. Weekly scouting was used to monitor insects and diseases for further sprays, which included permethrin (Pounce; FMC Corp., Philadelphia, PA), chlorothalonil (Bravo Ultrex Weatherstik; Syngenta Crop Protection, Greensboro, NC), and myclobutanil (Rally; Dow AgroSciences) for the conventional field and spinosad, pyrethrin (Pyganic; McLaughlin Gormley King, Minneapolis, MN), copper, sulfur, and neem oil (Trilogy; Certis USA, Columbia, MD) for the organically managed field. In 2013, one cucumber beetle per plant was the threshold for spraying. In 2014, the cucumber beetle thresholds were 0.5 beetle/plant preflowering, 1 beetle/ plant during fruit pollination, and 3 beetles/plant at vine touch. In 2013, the entire conventionally managed field was sprayed with a grass herbicide (Poast; BASF Corp., Research Triangle Park, NC) on 9 July. In both years, plots were hand weeded after rowcover removal.

\section{Data collection}

ENVIRONMENTAL MONITORING. Hobo temperature sensors (Onset Computer Corp., Bourne, MA) were placed 6 inches below soil surface between two plants within a row in three replications in the conventionally managed field. Temperature was recorded by the sensors every $60 \mathrm{~min}$ from date of transplant until last harvest. Temperature/light sensors (Hobo; Onset Computer Corp.) were attached to wooden stakes and installed between two plants within a row in three replications in the conventionally managed field. Sensors were 6 inches above soil surface. Air temperature and light intensity were recorded by the sensors every $30 \mathrm{~min}$ from date of transplant until last harvest. Soil moisture sensors (10HS; Decagon Devices, Pullman, WA) were inserted horizontally into an exposed surface of soil 6 inches below the surface between plants within a row in all no-rowcover treatments in four replications in the conventionally managed field. Soil moisture was measured only in the no-rowcover treatments because we were not interested in the effect of rowcover on soil moisture. The attached data loggers (Em5b; Decagon Devices) recorded volumetric water content every $60 \mathrm{~min}$ throughout the growing season until last harvest. Environmental monitoring occurred solely in the conventional fields because the differences in management systems (conventional and organic) in our experiment would likely not affect air or soil temperature or soil moisture.

Plant measurements. Before the first muskmelon harvest, three plants from each plot were excavated for measurement of vine length and plant biomass. All fruit were removed from vines and soil was removed from roots. In plots that had fewer than 10 living plants, only vine length was measured, thus retaining plants so that adequate harvest data could be collected. Vine length was measured from the base to the end of the vine. For plant biomass, plants were placed in paper bags and oven dried at $67^{\circ} \mathrm{C}$ for $5 \mathrm{~d}$ before weighing. Muskmelons were harvested at full slip, two to three times per week, from the 15 possible remaining plants. They were categorized as marketable if they weighed at least $2 \mathrm{lb}$, had adequate netting, and were free of damage caused by insects or pathogens. The number and total weight of marketable and nonmarketable (cull) melons were recorded for each plot. There were 12 harvests from 1 to 30 Aug. 2013 and five harvests from 14 to 29 Aug. 2014.

SOIL MICROBIAL BIOMASS CARBON. Soil samples were taken at the end of each growing season (29 Aug. 2013 and 29 Aug. 2014) in all "no rowcover" plots. Three soil cores (1.5 inches diameter, 6 inches depth) were taken within the row in the plots to make one composite sample per plot. Soil was kept in a sealed bag in a cooler at $4{ }^{\circ} \mathrm{C}$ until analysis. Soil samples were sieved using a $2-\mathrm{mm}$ sieve. The sieve size was deemed appropriate instead of a more common 8-mm sieve (Karlen et al., 2013; Vance et al., 1987) because the sandy texture of the soil made it easy to sieve without much disturbance to the soil even with a smaller mesh size. Microbial biomass carbon was extracted using a chloroform fumigation extraction method with a procedure modified from that of the Vance et al. (1987). In 2013, extracts were analyzed on an ultraviolet-persulfate total organic carbon (TOC) analyzer (Phoenix 8000; Teledyne Tekmar, Mason, OH). In 2014, a torch combustion TOC/TN analyzer (Teledyne Tekmar) was used. A conversion factor of 0.33 was used when calculating microbial biomass carbon. 


\section{Statistical analysis}

Data were analyzed using PROC GLIMMIX of SAS (version 9.3; SAS Institute, Cary, NC). Years and management systems (organic and conventional) were analyzed separately. Replication was treated as a random factor. Mean separation was performed by "Ismeans" and "pdiff" statements using the Satterthwaite method. Unprotected least significant difference was used, thereby allowing for comparisons between treatments even without significant main effects or interactions. This was important because the main research question was not about the whole plot or subplot treatments themselves, but about how they interact.

\section{Results}

WeAther. Monthly rainfall amounts during the 2013 and 2014 growing seasons were similar to 20 -year averages, except for unusually low rainfall amounts in Aug. 2013 (Table 2). Average monthly temperatures were similar to the 20year averages, with cooler than normal weather in July 2014.

SoIl Temperature. Production system had a more consistent effect on soil temperature than did rowcovers (Table 3 ). Before removal of rowcovers in 2013 , plasticulture increased daily mean and maximum soil temperature compared with ST by 1.7 and $2.7^{\circ} \mathrm{C}$, respectively, averaging across rowcover treatments. In 2014 before rowcovers were removed, plasticulture increased minimum and mean soil temperature by 1.7 and $2.0^{\circ} \mathrm{C}$, respectively, and rowcovers increased minimum soil temperature by $1.0^{\circ} \mathrm{C}$.

Once rowcovers were removed in 2013 , production system did not affect soil temperature. In 2014, minimum and mean soil temperatures remained $1.2{ }^{\circ} \mathrm{C}$ higher in plasticulture compared with ST after rowcovers were removed, and maximum soil temperatures in plasticulture plots were $1.4{ }^{\circ} \mathrm{C}$ higher. After rowcover removal in 2014, the plasticulture plots that previously had rowcovers had cooler soil than the plasticulture plots that had never had rowcovers. There was no interaction between system and rowcover in either year.

Air temperature AND Light INTENSITY. A strong storm on 17 June 2014 disrupted a number of sensors.

Table 2. Monthly total precipitation and average daily temperature during the 2013 and 2014 growing seasons and the 20-year average at the Muscatine Island Research and Demonstration Farm in Fruitland, IA. ${ }^{\mathrm{z}}$

\begin{tabular}{lccccccc}
\hline & \multicolumn{3}{c}{ Monthly precipitation $(\mathbf{m m})^{\mathbf{y}}$} & & \multicolumn{3}{c}{$\operatorname{Avg}$ monthly temp $\left({ }^{\circ} \mathbf{C}\right)^{\mathbf{y}}$} \\
\cline { 2 - 3 } Mo. & $\mathbf{2 0 1 3}$ & $\mathbf{2 0 1 4}$ & $\mathbf{2 0}$-yr $\mathbf{~ a v g ~}^{\mathbf{x}}$ & & $\mathbf{2 0 1 3}$ & $\mathbf{2 0 1 4}$ & $\mathbf{2 0}$-yr avg \\
\hline June & 154 & 125 & 136 & & 21.7 & 22.8 & 22.4 \\
July & 75 & 116 & 88 & & 23.3 & 21.7 & 24.4 \\
August & 1 & 107 & 104 & & 23.3 & 22.8 & 23.4 \\
\hline
\end{tabular}

${ }^{2}$ Monthly data from Iowa Environmental Mesonet at the Muscatine, IA, location.

${ }^{\mathrm{y}} 1 \mathrm{~mm}=0.0394$ inch, $\left(1.8 \times{ }^{\circ} \mathrm{C}\right)+32={ }^{\circ} \mathrm{F}$.

x 20 -year averages from 1995 to 2014 .

Table 3. Average daily minimum (Min), mean, and maximum (Max) soil temperature at 6 -inch $(15.24 \mathrm{~cm})$ depth in conventionally managed muskmelon before and after rowcover (RC) removal in 2013 and 2014 at the Muscatine Island Research and Demonstration Farm in Fruitland, IA. ${ }^{\mathrm{z}}$

\begin{tabular}{|c|c|c|c|c|c|c|c|}
\hline \multirow[b]{2}{*}{ System } & \multirow[b]{2}{*}{$\mathrm{RC}^{\mathrm{y}}$} & \multicolumn{3}{|c|}{ Pre RC removal $\left({ }^{\circ} \mathrm{C}\right)^{\mathrm{y}}$} & \multicolumn{3}{|c|}{ Post RC removal $\left({ }^{\circ} \mathrm{C}\right)$} \\
\hline & & Min & Mean & Max & Min & Mean & Max \\
\hline \multicolumn{8}{|c|}{2013} \\
\hline \multirow[t]{2}{*}{ Plasticulture } & $\mathrm{RC}$ & $24.3 \mathrm{a}^{\mathrm{x}}$ & $27.6 \mathrm{a}$ & $30.7 \mathrm{a}$ & 21.6 & $24.3 \mathrm{~b}$ & $26.3 \mathrm{a}$ \\
\hline & NRC & $24.1 \mathrm{ab}$ & $27.3 \mathrm{a}$ & $30.8 \mathrm{a}$ & 22.7 & $25.1 \mathrm{a}$ & $27.3 \mathrm{ab}$ \\
\hline \multirow[t]{2}{*}{ Strip tillage } & $\mathrm{RC}$ & $23.8 \mathrm{ab}$ & $26.1 \mathrm{~b}$ & $28.6 \mathrm{~b}$ & 22.5 & $24.4 \mathrm{ab}$ & $26.6 \mathrm{ab}$ \\
\hline & NRC & $23.3 \mathrm{~b}$ & $25.4 \mathrm{~b}$ & $27.4 \mathrm{~b}$ & 22.5 & $24.2 \mathrm{~b}$ & $25.9 \mathrm{~b}$ \\
\hline \multicolumn{8}{|c|}{ Significance } \\
\hline$S$ & & NS & $* * *$ & ** & NS & NS & NS \\
\hline $\mathrm{RC}$ & & * & NS & NS & NS & NS & NS \\
\hline $\mathrm{S} \times \mathrm{RC}$ & & NS & NS & NS & NS & NS & NS \\
\hline \multicolumn{8}{|c|}{2014} \\
\hline \multirow[t]{2}{*}{ Plasticulture } & $\mathrm{RC}$ & $24.7 \mathrm{a}$ & $28.1 \mathrm{a}$ & $31.8 \mathrm{a}$ & $23.5 \mathrm{a}$ & $25.7 \mathrm{~b}$ & $28.1 \mathrm{ab}$ \\
\hline & NRC & $23.6 \mathrm{~b}$ & $27.1 \mathrm{a}$ & $31.0 \mathrm{ab}$ & $23.9 \mathrm{a}$ & $26.4 \mathrm{a}$ & $29.0 \mathrm{a}$ \\
\hline \multirow[t]{3}{*}{ Strip tillage } & $\mathrm{RC}$ & $22.9 \mathrm{c}$ & $25.7 \mathrm{~b}$ & $28.8 \mathrm{~b}$ & $22.7 \mathrm{~b}$ & $24.7 \mathrm{c}$ & $26.9 \mathrm{c}$ \\
\hline & NRC & $22.0 \mathrm{~d}$ & $25.5 \mathrm{~b}$ & $30.1 \mathrm{ab}$ & $22.4 \mathrm{~b}$ & $24.9 \mathrm{c}$ & $27.5 \mathrm{bc}$ \\
\hline & \multicolumn{7}{|c|}{ Significance } \\
\hline$S$ & & $* * *$ & $* * *$ & NS & $* * *$ & $* * *$ & * \\
\hline $\mathrm{RC}$ & & $* * *$ & NS & NS & NS & * & NS \\
\hline $\mathrm{S} \times \mathrm{RC}$ & & NS & NS & NSNS & NS & NS & NS \\
\hline $\begin{array}{l}\text { "} \text { "Pre rowcover re } \\
2013,10 \text { July to } \\
{ }^{y}\left(1.8 \times{ }^{\circ} \mathrm{C}\right)+32 \\
{ }^{x} \text { Mean separatio } \\
\text { NRC }=\text { no rowc } \\
* * * * * *\end{array}$ & al: $5 \mathrm{Ju}$ & 17 July 2 & 11 June & July 2014 & rowco & & \\
\hline
\end{tabular}

Those sensors were repositioned 24 June 2014. Data from 17 to 24 June 2014 have been discarded.

Rowcovers increased daily mean and maximum air temperature compared with treatments without rowcovers, and increased daily minimum air temperature in 2014 (Table 4). Although rowcovers increased mean air temperature by 4.2 and $3.0^{\circ} \mathrm{C}$ in 2013 and 2014, respectively, maximum temperatures were increased by 11.7 and $6.1{ }^{\circ} \mathrm{C}$. Over both years, rowcovers reduced daily mean light intensity by $33 \%$ to $37 \%$ and daily maximum light intensity by $32 \%$ to $37 \%$.

SoIL MOIsTure. Production system had no significant effect on soil moisture in 2013, as seen in Table 5; however, daily minimum, mean, and maximum soil moisture during the midseason period was marginally $(P \leq$ $0.1)$ higher in ST than in plasticulture. In 2014, ST plots had higher minimum, mean, and maximum daily volumetric water content throughout the entire season.

Plant Growth. In 2013, there were interactions between the effect of production system and the effect of rowcover on plant biomass and vine length (Table 6); rowcovers more greatly increased melon plant biomass and vine length in plasticulture treatments than they did in ST treatments.

In 2014, rowcovers did not affect plant biomass or vine length 
(Table 6). Plants in plasticulture had more biomass than those in ST in both the organically and conventionally managed fields, whereas plants in plasticulture had longer vines only in the organically managed field.

YIELD. Production system had a significant effect on marketable muskmelon yield; plants grown in plasticulture produced more than those grown in ST in both years in the organic and conventional fields (Table 7). In the organically managed field, plasticulture treatments produced 7128 and $6732 \mathrm{lb} /$ acre more melon than ST in 2013 and 2014, respectively. In the conventionally managed field, plasticulture treatments produced 9900 and $9108 \mathrm{lb} /$ acre more melon than ST in 2013 and 2014 , respectively. Rowcovers had a significant effect on the yield only in the 2014 organic field, where ST with rowcover produced $4465 \mathrm{lb} /$ acre more melon than ST without rowcover. There was no interaction between production system and rowcover in regard to yield. Based on mean separation, the ST with rowcover treatment never produced an equivalent yield to either of the plasticulture treatments in the organically or conventionally managed fields in either year. However, in the conventional field in 2013, the ST without rowcover treatment produced the same yield as the plasticulture with rowcover treatment.

The average weight of each fruit was unaffected by production system except in the organic field in 2014, when melons from plants grown in plasticulture were $0.5 \mathrm{lb}$ heavier on average than those from plants grown

Table 4. Average daily minimum (Min), mean, and maximum (Max) air temperature and average daily mean and maximum light intensity in conventionally managed muskmelon in 2013 and 2014 before opening rowcovers (RC), averaged across production system treatments, at the Muscatine Island Research and Demonstration Farm in Fruitland, IA.

\begin{tabular}{|c|c|c|c|c|c|}
\hline \multirow[b]{2}{*}{ RC } & \multicolumn{3}{|c|}{ Air temp $\left({ }^{\circ} \mathrm{C}\right)^{\mathrm{z}}$} & \multicolumn{2}{|c|}{ Light intensity (lumens $\left./ \mathrm{m}^{2}\right)^{z}$} \\
\hline & Min & Mean & Max & Mean & Max \\
\hline & & & $2013^{y}$ & & \\
\hline RC & 17.4 & 31.5 & 53.0 & 310 & 1,248 \\
\hline \multirow[t]{3}{*}{ NRC } & 16.9 & 27.3 & 41.3 & 446 & 1,800 \\
\hline & NS & $* * *$ & $* * *$ & $* * *$ & $* * *$ \\
\hline & & & $2014^{x}$ & & \\
\hline RC & 15.7 & 29.4 & 48.4 & 312 & 1,238 \\
\hline \multirow[t]{2}{*}{ NRC } & 14.3 & 26.4 & 42.3 & 487 & 1,951 \\
\hline & ** & *** & $* * *$ & $* * *$ & $* * *$ \\
\hline
\end{tabular}

${ }^{\mathrm{z}}\left(1.8 \times{ }^{\circ} \mathrm{C}\right)+32={ }^{\circ} \mathrm{F}, 1$ lumen $/ \mathrm{m}^{2}=0.0929 \mathrm{fc}$.

'Rowcovers unopened 5 June to 10 July 2013.

${ }^{x}$ Rowcovers unopened 11 June to 9 July 2014. A storm disrupted rowcovers and sensors 17 June 2014; data from

17 to 24 June have been discarded.

$\mathrm{NRC}=$ no rowcover.

$\mathrm{NS},{ }^{*},{ }^{* *},{ }^{* *}$ Nonsignificant or significant at $P \leq 0.05,0.01$, or 0.001 , respectively, based on $\mathrm{F}$ test.

in ST. Rowcovers increased the average weight of melons in both years and in both organically and conventionally managed fields by 0.6 to 0.9 $\mathrm{lb}$, except in the conventional field in 2014 when rowcovers had no effect.

For nonmarketable (cull) weights in the 2013 organic field, there was an interaction between production system and rowcover, where rowcovers increased cull weights to a greater degree in plasticulture than in ST. In the 2014 organic field, both plasticulture and rowcovers increased cull weights and there was no interaction. In the conventional fields, rowcovers increased cull weights in both years. A large percentage of yield loss caused by insect damage on fruit was because of a sudden influx of cucumber beetles close to harvest for which insecticides were not applied.

\section{Discussion}

Soil temperatures were more affected by production system early in the season in 2013 when rowcovers were installed compared with later in the season when rowcovers had been removed. This could be due to the melon plants vining out and covering the surface of the black plastic as the season progressed, thus blocking solar radiation from heating the plastic mulch surface.

In previous studies, spunbonded rowcovers increased mean soil temperature at depths of $2.5 \mathrm{~cm}$ (Nair and Ngouajio, 2010), $5 \mathrm{~cm}$ (Motsenbocker and Bonanno, 1989), and $10 \mathrm{~cm}$ (Ibarra-Jiménez et al., 2004; Soltani et al., 1995). We did not see a strong effect by rowcovers on soil temperature at a depth of 6 inches. This was confirmed by Wolfe et al.

Table 5. Average daily minimum (Min), mean, and maximum (Max) soil moisture at 6-inch $(15.24 \mathrm{~cm})$ depth in conventionally managed muskmelon with no rowcovers at the Muscatine Island Research and Demonstration Farm in Fruitland, IA.

\begin{tabular}{|c|c|c|c|c|c|c|c|c|c|}
\hline \multirow[b]{2}{*}{ System } & \multicolumn{3}{|c|}{ Early season $\left(\mathrm{m}^{3} \cdot \mathrm{m}^{-3}\right)^{\mathrm{z}}$} & \multicolumn{3}{|c|}{ Midseason $\left(\mathrm{m}^{3} \cdot \mathrm{m}^{-3}\right)^{\mathrm{z}}$} & \multicolumn{3}{|c|}{ Late season $\left(\mathrm{m}^{3} \cdot \mathrm{m}^{-3}\right)^{\mathrm{z}}$} \\
\hline & Min & Mean & Max & Min & Mean & Max & Min & Mean & Max \\
\hline \multicolumn{10}{|c|}{2013} \\
\hline \multirow[t]{2}{*}{ Strip tillage } & 0.21 & 0.22 & 0.26 & 0.22 & 0.24 & 0.28 & 0.24 & 0.26 & 0.29 \\
\hline & \multicolumn{9}{|c|}{2014} \\
\hline & ** & ** & ** & $* * *$ & $* * *$ & $* * *$ & $\star * *$ & $* * *$ & ** \\
\hline
\end{tabular}

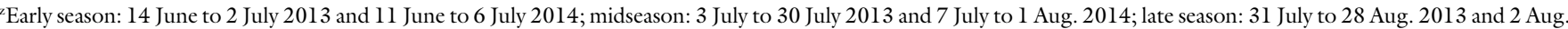
to 28 Aug. $2014 ; 1 \mathrm{~m}^{3}=35.3147 \mathrm{ft}^{3}$.

$\mathrm{NS},{ }^{*},{ }^{*},{ }^{* *}$ Nonsignificant or significant at $P \leq 0.05,0.01$, or 0.001 , respectively, based on $\mathrm{F}$ test. 
Table 6. Plant biomass and vine length of organically and conventionally managed muskmelon in 2013 and 2014 at the Muscatine Island Research and Demonstration Farm in Fruitland, IA.

\begin{tabular}{|c|c|c|c|c|c|}
\hline \multirow[b]{2}{*}{ System } & \multirow[b]{2}{*}{ RC } & \multicolumn{2}{|c|}{2013} & \multicolumn{2}{|c|}{2014} \\
\hline & & $\begin{array}{c}\text { Plant } \\
\text { biomass }(\mathrm{g})^{\mathrm{z}}\end{array}$ & $\begin{array}{c}\text { Vine } \\
\text { length }(\mathrm{cm})^{\mathrm{z}}\end{array}$ & $\begin{array}{c}\text { Plant } \\
\text { biomass }(\mathrm{g})\end{array}$ & $\begin{array}{c}\text { Vine } \\
\text { length }(\mathrm{cm})\end{array}$ \\
\hline \multicolumn{6}{|l|}{ Organic } \\
\hline \multirow[t]{2}{*}{ Plasticulture } & $\mathrm{RC}$ & $139 a^{y}$ & $277 \mathrm{a}$ & $97 \mathrm{a}$ & $183 \mathrm{a}$ \\
\hline & NRC & $70 \mathrm{~b}$ & $136 \mathrm{bc}$ & $80 \mathrm{ab}$ & $166 \mathrm{ab}$ \\
\hline \multirow[t]{3}{*}{ Strip tillage } & $\mathrm{RC}$ & $54 \mathrm{~b}$ & $161 \mathrm{~b}$ & $41 \mathrm{~b}$ & $138 \mathrm{bc}$ \\
\hline & NRC & $37 \mathrm{~b}$ & $117 \mathrm{c}$ & $30 \mathrm{~b}$ & $115 \mathrm{c}$ \\
\hline & & \multicolumn{4}{|c|}{ Significance } \\
\hline$S$ & & $* * *$ & $* * *$ & ** & ** \\
\hline $\mathrm{RC}$ & & * * & $* * *$ & NS & NS \\
\hline $\mathrm{S} \times \mathrm{RC}$ & & * & $* *$ & NS & NS \\
\hline \multicolumn{6}{|l|}{ Conventional } \\
\hline \multirow[t]{2}{*}{ Plasticulture } & $\mathrm{RC}$ & $148 \mathrm{a}$ & $271 \mathrm{a}$ & $76 a$ & $163 \mathrm{a}$ \\
\hline & NRC & $78 \mathrm{~b}$ & $175 \mathrm{~b}$ & $66 \mathrm{ab}$ & $143 \mathrm{ab}$ \\
\hline \multirow[t]{3}{*}{ Strip tillage } & $\mathrm{RC}$ & $60 \mathrm{~b}$ & $193 \mathrm{~b}$ & $43 \mathrm{c}$ & $140 \mathrm{~b}$ \\
\hline & NRC & $40 \mathrm{c}$ & $142 \mathrm{c}$ & $47 \mathrm{bc}$ & $139 \mathrm{~b}$ \\
\hline & & \multicolumn{4}{|c|}{ Significance } \\
\hline$S$ & & $* *$ & $* * *$ & $* * *$ & NS \\
\hline $\mathrm{RC}$ & & $* * *$ & $* * *$ & NS & NS \\
\hline $\mathrm{S} \times \mathrm{RC}$ & & $* *$ & $* *$ & NS & NS \\
\hline
\end{tabular}

${ }^{\mathrm{z}} 1 \mathrm{~g}=0.0353 \mathrm{oz}, \mathrm{l} \mathrm{cm}=0.3937$ inch.

'Mean separation (by year in columns) based on least significant differences at $P \leq 0.05$.

$\mathrm{RC}=$ rowcover, $\mathrm{NRC}=$ no rowcover, $\mathrm{S}=$ system

$\mathrm{NS},{ }^{*},{ }^{*},{ }^{* * *}$ Nonsignificant or significant at $P \leq 0.05,0.01$, or 0.001 , respectively, based on $\mathrm{F}$ test.

(1989), as they also did not see significant differences at the similar depth of $15 \mathrm{~cm}$. The soil in this study was a well-drained coarse sand, so one might expect the soil temperature to respond more quickly to temperature fluctuations than it would in a heavier soil; however, this was not observed at a depth of 6 inches. Soil temperature has been shown to be a predictor of vegetative growth in muskmelon (Jenni et al., 1996) and may be a better predictor of yield than air temperature (Ibarra et al., 2001).

Rowcovers increased maximum daily air temperature to a point that has been shown to be detrimental to muskmelon plants. Jenni et al. (1996) found that damage to muskmelon may occur when air temperature exceeds $40{ }^{\circ} \mathrm{C}$; this threshold was exceeded by 1.3 to $2.3{ }^{\circ} \mathrm{C}$ in no-rowcover treatments, and by 8.4 to $13.0{ }^{\circ} \mathrm{C}$ in rowcover treatments, depending on the year. Similarly, Ibarra et al. (2001) found that maximum air temperature under rowcovers reached 51.2 to $52.6^{\circ} \mathrm{C}$ as opposed to $37.2{ }^{\circ} \mathrm{C}$ in plots with no rowcover; they saw no positive effect of rowcovers on muskmelon yield. This suggests that the weight of rowcovers used in our experiment, $0.9 \mathrm{oz} / \mathrm{yard}^{2}$, perhaps contributed to higher than optimal air temperatures. If high temperatures appear to be damaging plants, we recommend using a rowcover that does not trap as much heat, such as a thinner spunbonded material or a nylon mesh. In addition, rowcovers could be removed or opened during hot periods; however, this would limit their usefulness in insect exclusion.

Since the muskmelons were grown in the summer and in full sun, the decreased light intensity under the rowcovers likely did not negatively affect their growth. Perring et al. (1989) found that only muskmelon grown under spunbonded rowcovers in the fall, as opposed to the spring, experienced yield loss. However, Nair and Ngouajio (2010) found that cucumber (Cucumis sativus) grown under a thick rowcover $(60 \%$ light transmission) sometimes produced lower yields than those grown under a light rowcover (85\% light transmission). It is hard to differentiate between the effect of temperature and light intensity, as thicker rowcovers trap more heat and block more light.

Strip tillage can increase soil moisture compared with conventional tillage without plastic mulch (Haramoto and Brainard, 2012), in part because organic residue on the ground in ST can decrease evaporation (Johnson and Hoyt, 1999). However, in this study, it is doubtful that the thin cereal rye mulch prevented more evaporation within the plant row than the film of plastic in plasticulture plots. Because we planted cereal rye in October, as opposed to the preferable September planting date to accommodate soybean harvest and because of the sandy soil at our site that lacks nutrients and organic matter, the cereal rye stand in both years was not thick enough to completely cover the soil after rolling. This not only allowed weeds to grow between rows, but also allowed for more evaporation and soil warming than would have been observed if the cereal rye residue had been thicker.

Whether in a reduced or conventional tillage system, organic mulches can help maintain greater soil moisture than plots covered in plastic mulch. Organic mulches allow rain to penetrate, whereas plastic films deflect most rainfall (Schonbeck and Evanylo, 1998). Both production systems in this study received the same amount of irrigation through drip tape, but most rainfall could not reach the plants in the plasticulture system, leading to more moisture in soils in ST (Table 5). If irrigation is limited or nonexistent in a certain farm setting, ST could provide a substantial benefit to muskmelon by allowing rain infiltration while minimizing evaporation.

Given that rowcovers, especially when combined with plasticulture, increased plant biomass in 2013, we do not believe the high temperature under the rowcovers negatively affected vegetative growth. This contradicts the assumption that air temperatures over $40{ }^{\circ} \mathrm{C}$ would have a negative effect on vine growth as suggested by Jenni et al. (1996). However, in 2014, rowcovers did not increase plant biomass or vine length. This was unexpected, as daily maximum air temperatures in 2013 in rowcover treatments were higher than those in 2014, and both were well over $40{ }^{\circ} \mathrm{C}$ (Table 4 ).

The significant interaction between system and rowcover in 2013 may have occurred because plots were not weeded until just after rowcovers were removed so as to not favor the no-rowcover treatment. There were 
Table 7. Marketable yield, marketable fruit weight, and nonmarketable (cull) weight of organically and conventionally managed muskmelon in 2013 and 2014 at the Muscatine Island Research and Demonstration Farm in Fruitland, IA.

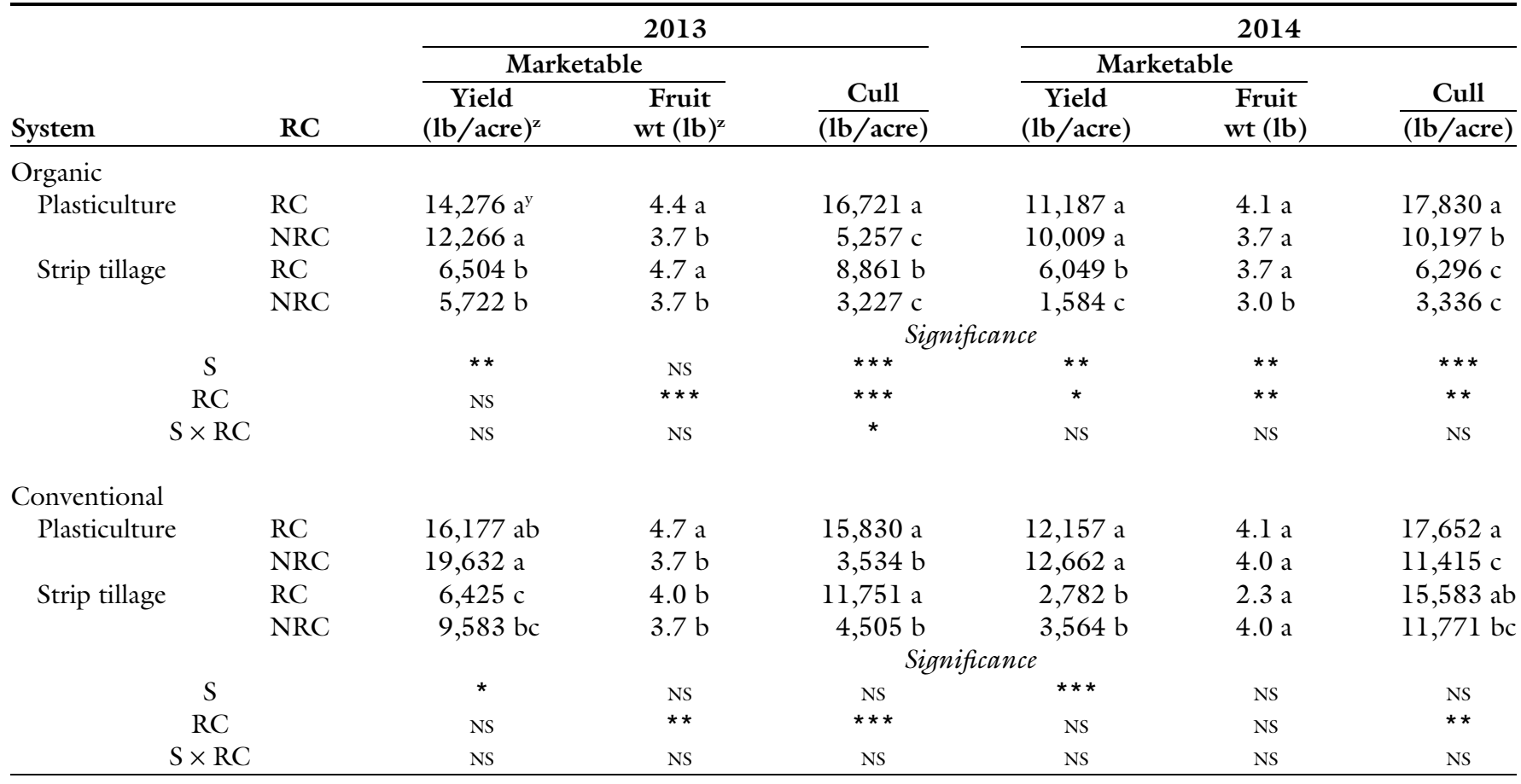

${ }^{2} 1 \mathrm{lb} / \mathrm{acre}=1.1209 \mathrm{~kg} \cdot \mathrm{ha}^{-1}, 1 \mathrm{lb}=0.4536 \mathrm{~kg}$.

'Mean separation in columns based on least significant differences at $P \leq 0.05$.

$\mathrm{RC}=$ rowcover, $\mathrm{NRC}=$ no rowcover, $\mathrm{S}=$ system.

Ns, ${ }^{*}, * *,{ }^{* *}$ Nonsignificant or significant at $P \leq 0.05,0.01$, or 0.001 , respectively, based on $\mathrm{F}$ test.

few weeds under the rowcovers in plasticulture plots, but weeds in ST plots did become problematic by that point in the season. Because of this, the rowcovers had a positive effect in plasticulture, but weed competition may have precluded this increase in melon plant biomass in ST. The same weeding protocol was used in 2014; however, the interaction was not observed.

Plant biomass and vine length of plants in ST with rowcover were the same as for plants in plasticulture without rowcover for both fields in both years with only one exception. This finding shows that ST can produce plants of similar size to those grown in a plasticulture system through the use of rowcovers.

In our study, plasticulture treatments produced higher marketable yields than ST across both years in conventional and organically managed fields. The only instance when rowcovers increased marketable yield compared with no-rowcover treatments was for organic ST plots in 2014 (Table 7). This supports the claim that soil temperature may be more important for muskmelon plant growth and yield than air temperature (Ibarra et al., 2001), because plasticulture systems tended to increase soil temperature at a 6 -inch depth, while rowcovers rarely affected it. Even though rowcovers should provide protection from insects and insect-transmitted diseases (Saalau Rojas et al., 2011), the treatment of ST with rowcovers did not ever produce an equivalent yield compared with plasticulture without rowcovers. The benefit that rowcovers have to offer may change from year to year depending on weather conditions, disease presence, and which, if any, insecticides are used after rowcover removal.

A reduction in tillage has been shown to increase soil microbial biomass over time (Karlen et al., 2013; Overstreet and Hoyt, 2008), indicating an improvement in soil health. We hypothesized that there would be higher soil microbial biomass carbon in ST treatments compared with plasticulture; however, we did not see a consistent difference in soil microbial biomass carbon between production systems (data not shown). In fact, the only significant difference we observed was in the 2013 conventionally managed field, where there was higher soil microbial biomass carbon in the plasticulture treatment than in ST treatment. This could be attributed to soil incorporation of cereal rye cover crop residue in the spring, providing microbes with an abundant source of carbon. It would likely take many years of reduced tillage to cause a measureable increase in soil microbial biomass carbon.

Planting date and soil type limited our ability to achieve a thick cereal rye mat, and results from a system with a thicker stand of cereal rye may be different. Studies have found that spunbonded rowcovers can increase marketable muskmelon yield (Cline et al., 2008) and increase early muskmelon yield (Motsenbocker and Bonanno, 1989). However, given that the system of rolled cereal rye depends on abundant biomass production and, especially in organic systems, the termination of cereal rye at anthesis stage to achieve successful termination, planting muskmelon early enough to capture the early season market would be challenging, even with rowcovers.

\section{Conclusions}

The goal of a ST system in rolled cover crops is to generate optimal 
cover crop biomass to provide weed control and moisture retention throughout the growing season. However, this often leads to delayed melon planting, as growers are supposed to wait until cereal rye reaches anthesis stage for effective termination using a roller crimper. This leads to challenges in early season melon production in a rolled cereal rye system. Because there is potential for building soil health through longterm reduction in tillage, $S T$ remains an important area of research. Rowcovers could be a useful tool in transitioning to reduced tillage systems. In this study, rowcovers did not increase marketable muskmelon yield, but did increase fruit weight and plant biomass. Controlling weeds remains a challenge in ST muskmelon production because of the slow vine growth and canopy closure, so achieving thick cereal rye mulch in ST is important, though it may prevent early planting.

\section{Literature cited}

Balota, E.L., A. Calegari, A.S. Nakatani, and M.S. Coyne. 2014. Benefits of winter cover crops and no-tillage for microbial parameters in a Brazilian oxisol: A longterm study. Agr. Ecosyst. Environ. 197:31-40.

Bottenberg, H., J. Masiunas, C. Eastman, and D. Eastburn. 1997. Yield and quality constraints of cabbage planted in rye mulch. Biol. Agr. Hort. 14:323-342.

Brainard, D.C. and D.C. Noyes. 2012. Strip tillage and compost influence carrot quality, yield, and net returns. HortScience 47:1073-1079.

Canali, S., G. Campanelli, C. Ciaccia, F. Leteo, E. Testani, and F. Montemurro. 2013. Conservation tillage strategy based on the roller crimper technology for weed control in Mediterranean vegetable organic cropping systems. Eur. J. Agron. 50:11-18.

Cline, G.R., J.D. Sedlacek, S.L. Hillman, S.K. Parker, and A.F. Silvernail. 2008. Organic management of cucumber beetles in watermelon and muskmelon production. HortTechnology 18:436-444.

Creamer, N.G. and S.M. Dabney. 2002. Killing cover crops mechanically: Review of recent literature and assessment of new research results. Amer. J. Altern. Agr. 17:32-40.

Delate, K. 2008. Effects of organic fertilization and cover crops on an organic pepper system. HortTechnology 18:215226.

Doran, J.W. 1987. Microbial biomass and mineralizable nitrogen distributions in no-tillage and plowed soils. Biol. Fertil. Soils 5:68-75.

Gogo, E.O., M. Saidi, J.M. Ochieng, T. Martin, V. Baird, and M. Ngouajio. 2014. Microclimate modification and insect pest exclusion using agronet improve pod yield and quality of french bean. HortScience 49:1298-1304.

Haramoto, E.R. and D.C. Brainard. 2012. Strip tillage and oat cover crops increase soil moisture and influence $\mathrm{N}$ mineralization patterns in cabbage. HortScience 47:1596-1602.

Hemphill, D.D., Jr. 1993. Agricultural plastics as solid waste: What are the options for disposal? HortTechnology 3:70-73.

Hoyt, G.D., D.W. Monks, and T.J. Monaco. 1994. Conservation tillage for vegetable production. HortTechnology 4:129-135.

Ibarra, L., J. Flores, and J.C. Dì̀az-Pérez. 2001. Growth and yield of muskmelon in response to plastic mulch and row covers. Sci. Hort. 87:139-145.

Ibarra-Jiménez, L., M.R. QuezadaMartín, and M. de la Rosa-Ibarra. 2004. The effect of plastic mulch and row covers on the growth and physiology of cucumber. Austral. J. Expt. Agr. 44:91-94.

Jackson, L.E., F.J. Calderon, K.L. Steenwerth, K.M. Scow, and D.E. Rolston. 2003. Responses of soil microbial processes and community structure to tillage events and implications for soil quality. Geoderma 114:305-317.

Jenni, S., D.C. Cloutier, G. Bourgeois, and K.A. Stewart. 1996. A heat unit model to predict growth and development of muskmelon to anthesis of perfect flowers. J. Amer. Soc. Hort. Sci. 121:274-280.

Johnson, A.M. and G.D. Hoyt. 1999. Changes to the soil environment under conservation tillage. HortTechnology 9:380-393.

Karlen, D.L., C.A. Cambardella, J.L. Kovar, and T.S. Colvin. 2013. Soil quality response to long-term tillage and crop rotation practices. Soil Tillage Res. 133:54-64.

Kasirajan, S. and M. Ngouajio. 2012. Polyethylene and biodegradable mulches for agricultural applications: A review. Agron. Sustainable Dev. 32:501-529.

Leavitt, M.J., C.C. Sheaffer, D.L. Wyse, and D.L. Allan. 2011. Rolled winter rye and hairy vetch cover crops lower weed density, but reduce vegetable yields in notillage organic production. HortScience 46:387-395.

Licht, M.A. and M. Al-Kaisi. 2005. Striptillage effect on seedbed soil temperature and other soil physical properties. Soil Tillage Res. 80:233-249.

Luna, J.M. and M.L. Staben. 2002. Strip tillage for sweet corn production: Yield and economic return. HortScience 37:1040-1044.

Mirsky, S.B., W.S. Curran, D.A. Mortensen, M.R. Ryan, and D.L. Shumway. 2009. Control of cereal rye with a roller/crimper as influenced by cover crop phenology. Agron. J. 101:1589-1596.

Motsenbocker, C.E. and A.R. Bonanno. 1989. Row cover effects on air and soil temperatures and yield of muskmelon. HortScience 24:601-603.

Nair, A. and M. Ngouajio. 2010. Integrating rowcovers and soil amendments for organic cucumber production: Implications on crop growth, yield, and microclimate. HortScience 45:566-574.

Nesmith, D.S., G. Hoogenboom, and D. V. McCracken. 1994. Summer squash production using conservation tillage. HortScience 29:28-30.

Overstreet, L.F. and G.D. Hoyt. 2008. Effects of strip tillage and production inputs on soil biology across a spatial gradient. Soil Sci. Soc. Amer. J. 72:1454-1463.

Peigné, J., B.C. Ball, J. Roger-Estrade, and C. David. 2007. Is conservation tillage suitable for organic farming? A review. Soil Use Mgt. 23:129-144.

Pelosi, C., B. Pey, M. Hedde, G. Caro, Y. Capowiez, M. Guernion, J. Peigné, D. Piron, M. Bertrand, and D. Cluzeau. 2014. Reducing tillage in cultivated fields increases earthworm functional diversity. Appl. Soil Ecol. 83:79-87.

Perring, T.M., R.N. Royalty, and C.A. Farrar. 1989. Floating row covers for the exclusion of virus vectors and the effect on disease incidence and yield of cantaloupe. J. Econ. Entomol. 82:1709-1715.

Rapp, H.S., R.R. Bellinder, H.C. Wien, and F.M. Vermeylen. 2004. Reduced tillage, rye residues, and herbicides influence weed suppression and yield of pumpkins. Weed Technol. 18:953-961.

Roper, M.M., V.V.S.R. Gupta, and D.V. Murphy. 2010. Tillage practices altered labile soil organic carbon and microbial function without affecting crop yields. Austral. J. Soil Res. 48:274-285.

Saalau, R.E., M.L. Gleason, J.C. Batzer, and M. Duffy. 2011. Feasibility of delaying 
removal of row covers to suppress bacterial wilt of muskmelon (Cucumis melo). Plant Dis. 95:729-734.

Salem, H.M., C. Valero, M.A. Muñoz, M. G. Rodríguez, and L.L. Silva. 2015. Shortterm effects of four tillage practices on soil physical properties, soil water potential, and maize yield. Geoderma 237:60-70.

Schonbeck, M.W. and G.K. Evanylo. 1998. Effects of mulches on soil properties and tomato production I. Soil temperature, soil moisture and marketable yield. J. Sustain. Agr. 13:55-81.
Smith, A.N., C. Reberg-Horton, G.T. Place, A.D. Meijer, C. Arellano, and J.P. Mueller. 2011. Rolled rye mulch for weed suppression in organic no-tillage soybeans. Weed Sci. 59:224-231.

Soltani, N., J.L. Anderson, and A.R. Hamson. 1995. Growth analysis of watermelon plants grown with mulches and rowcovers. J. Amer. Soc. Hort. Sci. 120:1001-1009.

Vance, E.D., P.C. Brookes, and D.S Jenkinson. 1987. An extraction method for measuring soil microbial biomass C. Soil Biol. Biochem. 19:703-707.
Wolfe, D.W., L.D. Albright, and J. Wyland. 1989. Modeling row cover effects on microclimate and yield: I. Growth response of tomato and cucumber. J. Amer. Soc. Hort. Sci. 114:562-568.

Wyland, L.J., L.E. Jackson, W.E. Chaney, K. Klonsky, S.T. Koike, and B. Kimple. 1996. Winter cover crops in a vegetable cropping system: Impacts on nitrate leaching, soil water, crop yield, pests and management costs. Agr. Ecosyst. Environ. 59:1-17. 